\title{
KINETICS OF THE ADSORPTION OF TEXTILE DISPERSE DYE TO MODIFIED POLYETHYLENE TEREPHTHALATE
}

Marija Kodrić1*, Radica Kristić ${ }^{2}$, Ivan Ristić ${ }^{3}$, Milena Nikodijević Dragan Djordjevic ${ }^{2}$

1University of Nis, Innovation Center, Nis, Serbia

2University of Niš, The Faculty of Technology, Leskovac, Serbia

3 University of Novi Sad, The Faculty of Technology, Novi Sad, Serbia

Kinetics of the dyeing process of modified polyethylene terephthalate with disperse dye are shown in this paper. The modification of the fibers was performed with an aqueous solution of slaked lime with the simultaneous action of ultrasonic waves. The dyeing of the fibers was performed in a discontinuous-batch process, with a change in the initial dye concentration (20 - $120 \mathrm{mg} \mathrm{dm}^{-3}$ ) and dyeing time (5 - 60 min). Several kinetic reactions (Pseudo first, Avrami and Modified Freundlich) and diffusion models (Weber\&Morris, Boyd, and Film diffusion) were used to test the experimental data from the dyeing process. It has been found that dyeing of modified fibers gives better results than dyeing of unmodified polyester, under the same conditions. With the increase of the initial dye concentration, a degree of exhaustion decreases (76,2 - 57,4 \%, for equilibrium time of dyeing) and the absorption of disperse dyes per unit mass of fibers increases $\left(1,5-6,9 \mathrm{mg} \mathrm{g}^{-1}\right.$, for equilibrium time of dyeing). During the dyeing process, the initial concentration of the dye decreases, whereas the capacity of the adsorption increases. A linear simulation of the kinetic dyeing parameters showed that the Modified Freundlich reaction model dominated, while of the kinetic diffusion models the Boyd equation was most favorable.
(ORIGINAL SCIENTIFIC PAPER) UDC 677.027:678.742.2

Keywords: polyethylene terephthalate, modification, slaked lime, ultrasound, disperse dye, kinetic models

\section{Introduction}

Polyethylene terephthalate (PET) fiber belongs to the group of polyester fibers and is widely used in the clothing industry. The fiber is crystalline with the compact structure and is prominently hydrophobic. It is mainly dyed with non-ionic dyes (usually disperse dyes) The modification of the fibers was performed with an aqueous solution of slaked lime with the simultaneous action of ultrasonic waves which have low solubility in water under the specific conditions: high temperature, higher pressure or the presence of a carrier. The low solubility in water and the particle size of the non-ionic dye play a vital role in the dissolution rate and the rate of the dye adsorption for the PET fiber [1,2].

Chemically, disperse dyes usually contain anthraquinone, diphenylamine, or methine and azo groups. These dyes usually contain $\mathrm{NO}_{2}, \mathrm{CN}, \mathrm{OH}$, halogens, as well as groups of primary, secondary and tertiary amines, but they almost never contain polar groups that are easily ionized in a water bath. They generally have a low molecular mass which facilitates their penetration and the diffusion to highly crystalline PET fibers. The higher the molecular mass of the dye, the slower the diffusion in the fibers [2].

The structure of PET fibers does not affect the dyeing mechanism regardless of the dyeing procedures, because the fiber does not absorb a significant amount of water, the dye is adsorbed only in amorphous regions, i.e. it does not enter the crystal regions of the fiber. During the dyeing process, the diffusion rate of the dye molecule towards the fiber surface is always greater than the diffusion rate in the fiber [3]. Therefore, the rate towards the surface does not show any effect on the total dyeing rate, while the diffusion of the dye within the fiber is the step that determines the dyeing rate. A disperse dye tends to precipitate on the fiber surface since the surface of the PET fiber is full of hydrophobic $\mathrm{C}-\mathrm{O}-\mathrm{C}$ bonds, while the hydrophilic $\mathrm{C}=\mathrm{O}$ are faced toward the interior of the fiber [3].

As it is very difficult to obtain the adequate strong, darker shades at polyester dyeing under normal conditions (temperature and pressure), it is very important to develop new dyeing methods so that the dyeing rate and the color absorption could be increased. Greater fiber permeability through the increased fiber swelling capacity is a prerequisite for increasing the diffusion rate of the dye. Among other methods, hydrolytic modification of the surface of PET materials with or without ultrasound is interesting, e.g. alkali treatment, when changes occur only at the surface, while the inner morphological structure of the fibers remains preserved $[4,5]$.

\footnotetext{
*Author address: Marija Kodrić, University of Niš, Innovation Center, Niš, Univerzitetski trg 2 18000, Niš, Serbia

E-mail: izida50@gmail.com

The manuscript received: April,23, 2020.

Paper accepted: May, 18, 2020.
} 
This article aims to clarify the dye adsorption process for previously physico-chemically modified PET fibers by analyzing the rate and the dyeing mechanism. The aim of the research is to successfully perform the dyeing of the hydrolyzed hydrophobic fiber and to clarify the events in the dye-PET fiber interactions, to discover the dyeing mechanism and to extrapolate the results to the operating conditions.

\section{Experiment}

Raw, undyed $100 \%$ polyethylene terephthalate (PET) fibers with the following characteristics were used: length $85 \mathrm{~mm}$, fineness 1.7 dtex, tenacity 51.7 $\mathrm{cN}$ tex $^{-1}$, elongation at break $30 \%$.

Previous preparation of PET fibers, prior to dyeing, consisted of a treatment with the aqueous calcium hydroxide solution (slaked lime, Laboratorija doo, Serbia) $60 \mathrm{~g} \mathrm{dm}^{-3}$ under the following conditions: the dye bath ratio $1: 100$, the treatment temperature $80^{\circ} \mathrm{C}$, the processing time $90 \mathrm{~min}$, ultrasound with the frequency of $200 \mathrm{kHz}$ and the power of $50 \mathrm{~W}$ (Elac Ultrasonic Laboratory Reactor URS 1000).

Dyeing of the PET fibers was performed by using C.I. Disperse Yellow $42\left(\mathrm{C}_{18} \mathrm{H}_{15} \mathrm{~N}_{3} \mathrm{O}_{4} \mathrm{~S} ; \mathrm{M}=369.4 \mathrm{~g} \mathrm{~mol}^{-1}\right)$. The structural formula of the applied color obtained by software modeling (ChemBioDraw Ultra 14.0) is shown in Figure 1.

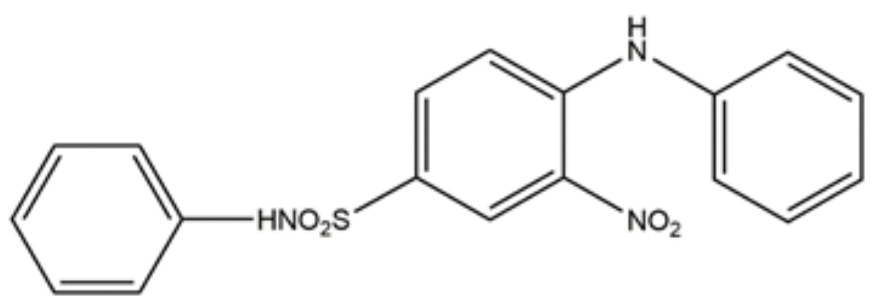

Figure 1. Structure of the used Disperse Yellow 42

A batch (discontinuous) process was used to check the kinetic parameters of the dyeing process. The fiber sample was dyed in a dye bath of the constant volume $0.1 \mathrm{dm}^{3}$ and the constant temperature $98{ }^{\circ} \mathrm{C}$. The time varied from 5 to $60 \mathrm{~min}$ and the concentrations of the dye from 20 to $120 \mathrm{mg} \mathrm{dm}^{-3}$. The dispersing agent Alviron W (Texticolor, Switzerland) $1 \mathrm{~g} \mathrm{dm}^{-3}$ and acetic acid (Tehnohemija a.d., Serbia) for $\mathrm{pH} 5$, were used as additives.

UV-VIS spectrophotometry and a Cary 100 Conc UVVIS Varian $\left(\lambda_{\max }=440 \mathrm{~nm}\right.$ ) were used to determine the concentration of the dye in the solution.

The degree of dye exhaustion was calculated by using the equation [6]:

Degree of exhaustion $=\frac{C_{0}-C_{t}}{C_{0}} \cdot 100$

where: $C_{0}$ and $C_{t}$ - the initial and dye concentrations in dying time $t\left(\mathrm{mg} \mathrm{dm}^{-3}\right)$.

The amount of the adsorbed dye or the adsorption capacity was obtained by using the equations [6]: $q_{t}=\frac{c_{0}-c_{t}}{w} \cdot v$ and $q_{e}=\frac{c_{0}-c_{e}}{w} \cdot$

where: $q_{t}$ - the adsorption capacity in dyeing time $t\left(\mathrm{mg} \mathrm{g}^{-1}\right)$; $q_{e}$ - the adsorption capacity in equilibrium $\left(\mathrm{mg} \mathrm{g}^{-1}\right) ; C_{0}-$ the initial dye concentration $\left(\mathrm{mg} \mathrm{dm}^{-3}\right) ; C_{t}$ - the dye concentration in the solution in dyeing time $t\left(\mathrm{mg} \mathrm{dm}^{-3}\right) ; C_{e}$ - equilibrium dye concentration in the solution $\left(\mathrm{mg} \mathrm{dm}^{-3}\right)$; $w$ - the mass of the fiber $(\mathrm{g}) ; V$ - the volume of the dyeing solution $\left(\mathrm{dm}^{3}\right)$.

\section{Kinetic reaction models}

The kinetics of a disperse yellow dye at sorption on PET fibers were analyzed using the following reaction kinetic models: Pseudo first, Avrami and Modiffied Freundlich.

The adsorption kinetic data described by Pseudo first order model represent the first known equation, which describes the adsorption rate based on the adsorption capacity [7]:

$\log \left(q_{e}-q_{t}\right)=\log \left(q_{e}\right)-\frac{k_{1}}{2.303} \cdot t$

where: $q_{e}$ and $q_{t}$ are adsorption capacities at equilibrium and after time $t$, respectively $\left(\mathrm{mg} \mathrm{g}^{-1}\right)$, and $k_{1}$ is the Pseudo-first order adsorption rate constant $\left(\mathrm{min}^{-1}\right)$.

The Avrami model defines certain kinetic parameters, e.g. possible changes in the adsorption rate as a function of the initial concentration and adsorption time, as well as the determination of the kinetic order of the fractions [8]:

$q_{t}=q_{e} \cdot\left\{1-\exp \left[-\left(K_{A} \cdot t\right)\right]^{\mathrm{n}} \mathrm{A}\right.$

where $q_{t}$ - the adsorption capacity at time $t ; K_{A}$ - kinetic constant $\left(\min ^{-1}\right)^{-n_{A V}} ; n_{A}$ - the constant associated with the adsorption mechanism.

The Modified Freundlich equation has the following form [9]:

$q_{t}=k_{m F} \cdot C_{0} \cdot t^{1 / m_{m F}}$

where, $k_{m F}$ is the apparent adsorption constant $\left(\mathrm{dm}^{3} \mathrm{~g}^{-1}\right.$ $\left.\min ^{-1}\right) ; C_{0}$ - the initial dye concentration $\left(\mathrm{mg} \mathrm{dm}^{-3}\right) ; t$ is contact time ( $\mathrm{min}) ; m_{m F}$ is Kuo-Lhotse constant.

Kinetic diffusion models

The following kinetic diffusion models were processed in the study: Weber\&Morris, Boyd, and Film diffusion.

Weber\&Morris or the particle diffusion model has the following equation [7]:

$q_{t}=k_{W M} \cdot t^{0.5}$

where, $k_{w m}$ is a constant speed within the particle diffusion ( $\left.\mathrm{mg} \mathrm{g}^{-1} \mathrm{~min}^{-0.5}\right) ; t$ is contact time ( $\left.\mathrm{min}\right)$.

The Boyd model of the particle diffusion is one of the most commonly used models for studying the adsorption 
mechanism [10]:

$F<0,85, B t=\left(\pi^{\frac{1}{2}}-\left(\pi-\frac{\pi^{2} \cdot F}{3}\right)^{\frac{1}{2}}\right)$.

$F<0,85, B t=-0,4997-\ln (1-F)$

$F=\frac{q_{t}}{q_{e}}$

$F$ is the fraction of the solute adsorbed at any time $t$.

The Bt vs $t$ diagram is drawn and the sorption mechanism is discussed from the fit curve. The slope of the Boyd plot can be used to calculate $B$ values $\left(\mathrm{s}^{-1}\right)$ for the determination of the effective diffusion coefficient, $D i$ $\left(\mathrm{cm}^{2} \mathrm{~s}^{-1}\right)$.

Film diffusion equation is written as [10]:

$q_{t}=q_{e}-q_{e} \cdot e^{-K_{F D} \cdot t}$

where, $k_{F D}$ is the external mass transfer coefficient $\left(\min ^{-1}\right)$; $t$ is contact time ( $\mathrm{min})$.

The calculation, as well as the fit of isothermal equations to the kinetic data were checked and compared on the basis of several statistical parameters (error functions) shown in Table 1 [9]. The calculation was successfully realized using the computer software OriginPro.

Table 1. Lists of non-linear error functions

\begin{tabular}{lcl}
\hline Error function & Abbreviation & Definition/expression* \\
\hline Sum squares error & $S S E$ & $\sum_{i=1}^{n}\left(q_{\text {calc }}-q_{\text {exp }}\right)_{i}^{2}$ \\
The coefficient of determination & $R^{2}$ & $\frac{\left(q_{\text {exp }}-\bar{q}_{\text {calc }}\right)^{2}}{\sum_{i=1}^{n}\left(q_{\text {exp }}-\bar{q}_{\text {calc }}\right)^{2}+\left(q_{\text {exp }}-q_{\text {calc }}\right)^{2}}{ }_{i}$ \\
Residual root mean square error & RMSE & $\sqrt{\frac{1}{n-2}} \cdot \sum_{i=1}^{n}\left(q_{\text {exp }}-q_{\text {calc }}\right)^{2}$
\end{tabular}

\section{Results and discussion}

\section{Dyeing properties}

Polyethylene terephthalate, like all polyesters, is sensitive to alkalis; the treatment in a weakly alkaline solution with ultrasound increases the porosity of the fibers, accelerates the sorption and the diffusion of the dye [5].

The influence of the dye concentration on its exhaustion and adsorption capacity over time is shown in Figure 2. A degree of the exhaustion decreases with the increase of the initial dye concentration, depending on time of dyeing. At lower dye concentrations, initially there is a slight decrease in the percentage of the exhausted dye, and eventually this decrease is stronger.

As expected, the shortest dyeing time ( $5 \mathrm{~min}$ ) causes the lowest degree of exhaustion, while the longest dyeing time (60 $\mathrm{min}$ ) results in the highest value of this parameter.

It is also noticeable (Figure 2) that the adsorption capacity increases with the increase of the initial dye concentration, Namely, the adsorption of a disperse dye per unit mass of PET fibers increases continuously during the time. As the initial concentrations increase, $q_{t}$ slightly increases, a slowdown occurs because the dye is adsorbed on the surface of the fibers and the rest of the dye molecules are evenly distributed in the dyeing bath due to the thermal movement of the dye molecules.

The following values can be seen from Figure 2: the maximum value of the degree of exhaustion is $76.2 \%$ (the initial dye concentration of $20 \mathrm{mg} \mathrm{dm}^{-3}$, dyeing time $60 \mathrm{~min}$ ), while the maximum value of the adsorption capacity is $6.89 \mathrm{mg} \mathrm{g}^{-1}$ (the initial dye concentration of 120 $\mathrm{mg} \mathrm{dm}^{-3}$, dyeing time $60 \mathrm{~min}$ ).

Regarding the dyeing of the unmodified PET fiber, the following data were obtained: a degree of exhaustion was $64 \%$ (the initial dye concentration of $20 \mathrm{mg} \mathrm{dm}^{-3}$, dyeing time $60 \mathrm{~min}$ ), and the maximum value of the adsorption capacity was $5.1 \mathrm{mg} \mathrm{g}^{-1}$ (the initial dye concentration 120 $\mathrm{mg} \mathrm{dm}^{-3}$, dyeing time $60 \mathrm{~min}$ ).

According to these data, the dyeing of the modified PET fiber with a disperse yellow dye has far better results in favor of the use of pretreatment before dyeing.

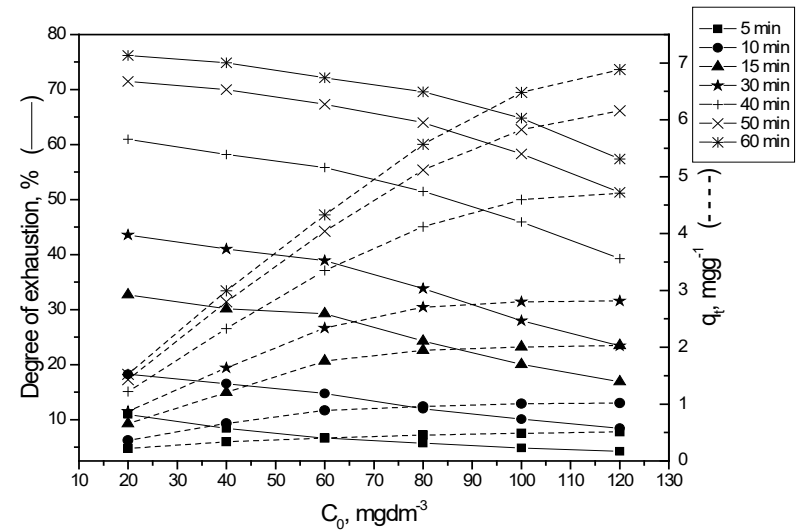

Figure 2. Effect of initial dye concentration on degree of exhaustion and adsorption capacity for different dyeing time

The diagram in Figure 3 shows the changes in the dye concentration in the dye bath and on the PET fiber during dyeing for different initial concentrations. A gradual change in the concentration of the dye in the dye bath during dyeing is noticed, at first more intense and later somewhat slower. Higher dye concentrations have a steeper drop in their curves at the beginning of dyeing, which is associated with a sudden binding of the dye to the fibers at the beginning, given a large difference in the concentration gradient.

The beginning of dyeing brings a gradual change in the binding of the dye to the PET fiber, and later, over time, this binding is slower. At the highest initial dye concentrations and the longest dyeing time, the highest dye adsorption occurs for the fiber. 


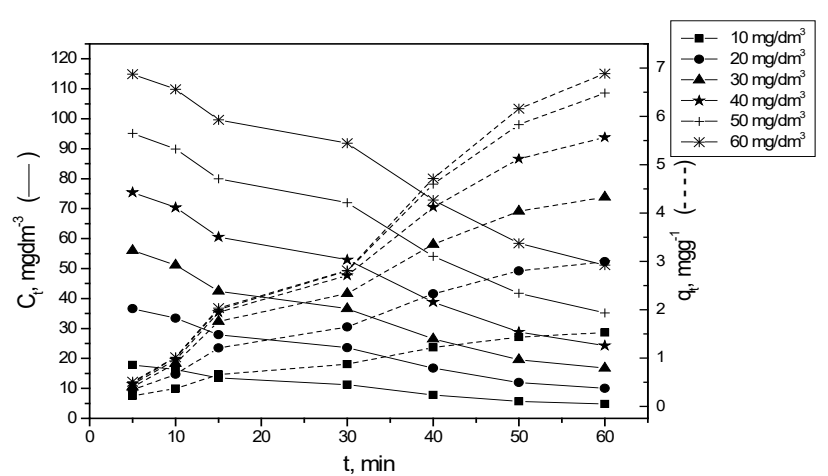

Figure 3. Change of concentration and adsorption capacity during dyeing for different initial dye concentrations

Similar results of the researchers confirm a greater degree of the exhaustion paint during dyeing variously modified PET textiles (ultrasound, plasma, etc.) compared to the unmodified samples $[11,12]$.

\section{Adsorption kinetic models}

The information on the dyeing kinetics is important for determining the optimum working conditions for a full batch process. Adsorption kinetics can be represented by a graph of the absorption with respect to time and this dependence (diagram) is known as the kinetic isotherm. Kinetics depends on material factors such as adsorbent and adsorbate, as well as experimental factors such as temperature or $\mathrm{pH}[9]$.

Figures 4-6 present kinetics of dye adsorption on fibers and linear kinetic reaction models, Pseudo first, Avra$m i$ and Modified Freundlich for all initial concentrations of disperse yellow dye. According to the model curves that fit the experimental points, the Modified Freundlich equation best describes the kinetics of the color adsorption, Fig. 6 , i.e. the curves of this model follow the paths closest to the experimental points. At the same time, according to the appearance of the curves in the diagram in Figure 4, the Pseudo first order model lags far behind the other models and has a smaller contribution in elucidating the sorption kinetics.

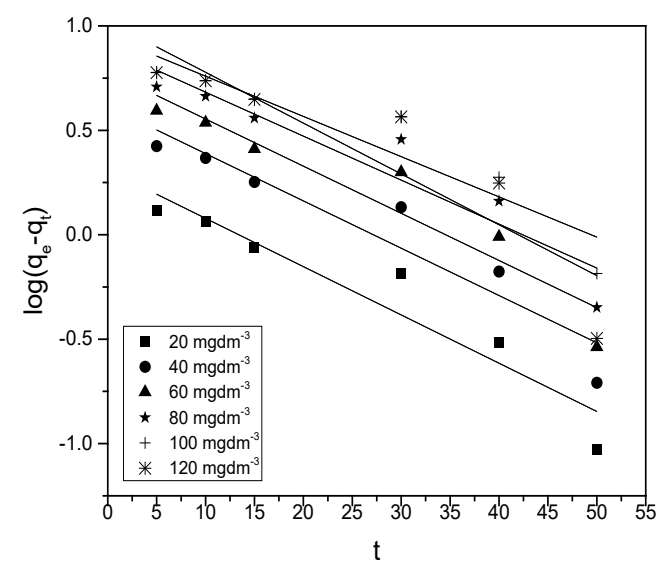

Figure 4. Adsorption kinetic of disperse yellow dye according to the Pseudo first order kinetic reaction model

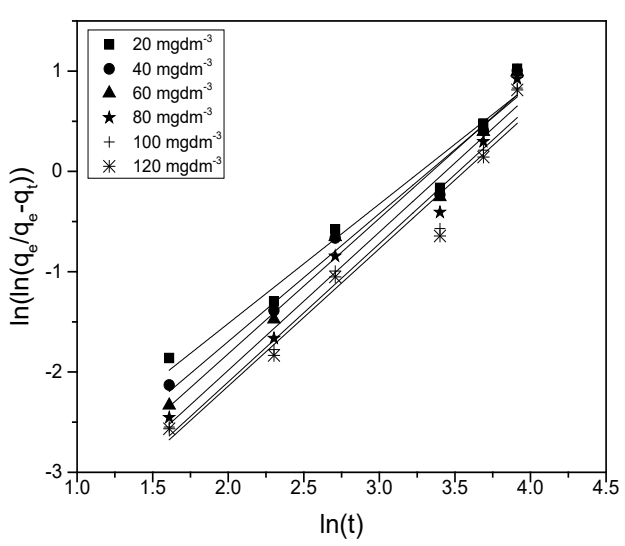

Figure 5. Adsorption kinetic of disperse yellow dye according to the kinetic reaction model of Avrami

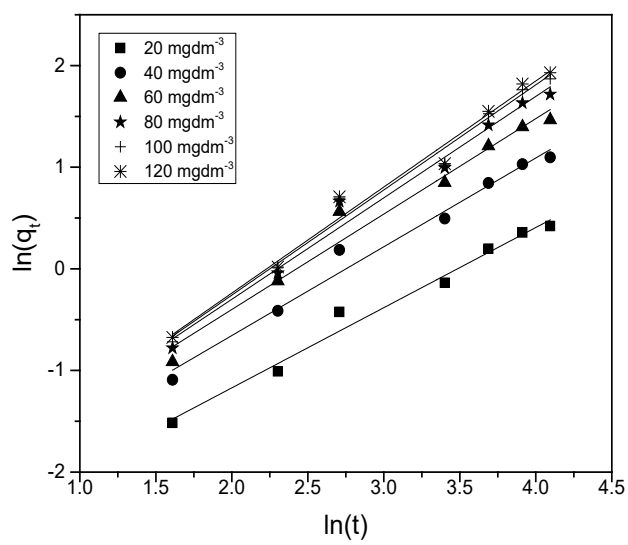

Figure 6. Adsorption kinetic of disperse yellow dye according to the Modified Freundlich kinetic reaction model

Table 2 shows the value of numerous parameters of kinetic reaction models for the dye adsorption for both minimum and maximum initial concentrations (20 and $120 \mathrm{mg} \mathrm{dm}^{-3}$ ), respectively. The kinetic parameters have the same tendency and similar values for all other initial dye concentrations. Based on the maximum values of the coefficient of determination $\left(R^{2}>0.98\right)$, as well as the lowest values of the error parameters (SSE $=0.053$ and $R M S E=0.103$ ), a superior and perfect fit of the experimental results to the Modified Freundlich kinetic model was confirmed for both dye concentrations.

According to the data in Table 2, the Pseudo first order kinetic model proved to be the most unsuitable one, meaning that the adsorption rate cannot be described solely on the basis of the adsorption capacity and that the change in the adsorption rate does not depend on the initial concentration and reaction time, only.

Avrami equation was used to verify specific changes in kinetic parameters during dyeing. The data suggest that the dyeing process is a limited surface reaction, the diffusion of dye molecules is rapid $\left(n_{A}>1\right)$, and that the transfer of dye molecules to the interface (border sur- 
face) is not a step that controls the dyeing rate. Since it is an exponential equation, $n_{A}$ as a fraction number, is associated with possible changes in the adsorption mechanism that occurs during dyeing, so the adsorption mechanism can be followed by multiple orders of kinetics that change during the contact of the adsorbate with the adsorbent.

The best results for the coverage of the experimental points obtained by the Modified Freundlich model suggest that the adsorption energy decreases exponentially by surface saturation, and it is a fast adsorption reaction at the beginning followed by a subsequent slower adsorption rate. Diffusion processes are controlled by the surface. and kinetics controlled within particle (interparticle) diffusion is favored.

Table 2. Parameters of kinetic reaction models with statistical error parameters

\begin{tabular}{lrcc}
\hline \multirow{2}{*}{ Kinetic models } & \multicolumn{3}{c}{$\begin{array}{c}\text { Initial dye concentration, } \\
\mathrm{mg} \mathrm{dm}^{-3}\end{array}$} \\
\hline$k_{1}\left(\mathrm{~min}^{-1}\right)$ & 0.053 & 0.056 \\
$q_{e}\left(\mathrm{mg} \mathrm{g}^{-1}\right)$ & 2.041 & 10.504 \\
Pseudo first & $S S E$ & 0.088 & 0.222 \\
$R^{2}$ & 0.906 & 0.810 \\
RMSE & 0.148 & 0.235 \\
Avrami & $K_{A}\left(\mathrm{~min}^{-1}\right)^{-n_{A V}}$ & 0.00053 & 0.00027 \\
$n_{A}$ & 1.192 & 1.370 \\
& $S S E$ & 0.213 & 0.328 \\
$R^{2}$ & 0.963 & 0.957 \\
& $R M S E$ & 0.231 & 0.286 \\
Modified Freundlich & $k_{m F}\left(\mathrm{dm}^{3} \mathrm{~g}^{-1} \mathrm{~min}^{-1}\right)$ & 0.0032 & 0.0049 \\
& $m_{m F}$ & 1.268 & 0.958 \\
$S S E$ & 0.053 & 0.088 \\
$R^{2}$ & 0.983 & 0.984 \\
& $R M S E$ & 0.103 & 0.133 \\
\hline
\end{tabular}

In a similar research, the adsorption behavior of dyeing polyester fibers in supercritical carbon dioxide at $95^{\circ} \mathrm{C}$ and 300 bar was treated using a disperse dye, C.I. Disperse Orange 30. The pseudo-first and pseudo-second order kinetic models were used to describe the dyeing rate. According to the estimated rate constants of dyeing polyester and the values of correlation coefficients, it has been shown that the kinetic pseudo-second order model was a better fit to the experimental data [7].

\section{Adsorption mechanism}

From a design perspective, a more extensive approach to kinetic modeling would be sufficient to describe the rate of sorption. However, in order to understand the mechanism which controls the complete sorption kinetics, kinetic diffusion models or mechanistic (theoretical) models are preferred. From a mechanistic point of view, in order to interpret the experimental data, it is necessary to identify the steps involved in adsorption described by the external mass transfer (diffusion through the border layer) and the diffusion within particles [10].

Figures 7-9 show the dyeing rate diagrams with experimental points and selected kinetic diffusion models Weber\&Morris and Boyd and Film diffusion for all initial disperse dye concentrations. According to the appearance of all curves that fit the experimental points, Boyd and Weber\&Morris equations best describe the dye diffusion kinetics, i.e. the curves of both models are closest to the experimental points for all initial concentrations. It should be noted that preference is given to the Boyd model, which is better by form of the curve and statistical parameters, Tab. 3.

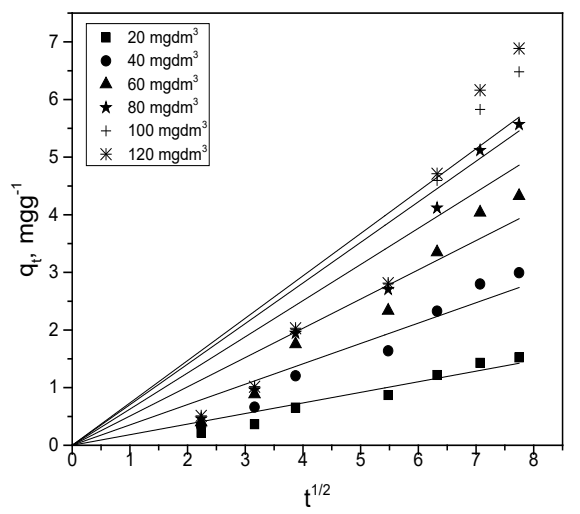

Figure 7. Adsorption kinetic of disperse yellow dye according to the Weber\&Moris mechanistic model

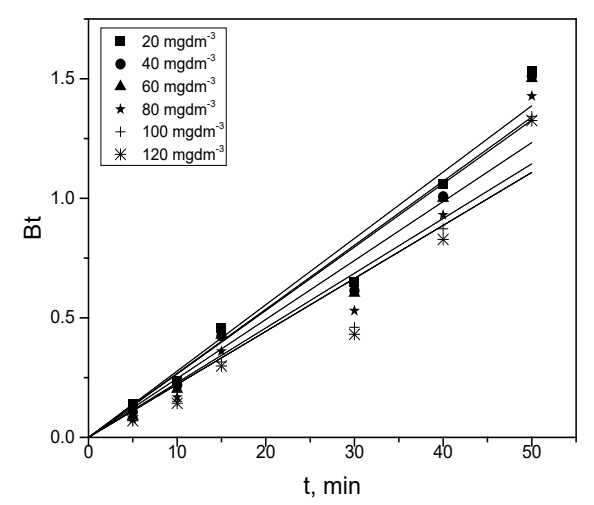

Figure 8. Adsorption kinetic of disperse yellow dye according to the Boyd mechanistic model

Table 3 shows the exact results of the kinetic diffusion equation parameters for the dye diffusion of the initial concentrations of 20 and $120 \mathrm{mg} \mathrm{dm}^{-3}$. The results showed that all the applied models (Weber\&Morris, Boyd and Film diffusion), have high coefficients of deter- 
mination $\left(R^{2}<0.9\right)$ and low values of error parameters (SSE < 0.062; RMSE < 0.111). Nevertheless, the most prominent is the Boyd model since its curve best covers the experimental points and has the most favorable statistical parameters for the validity of the model.

The Boyd model was applied to analyze the rate-limiting step, the diffusion within particles or the diffusion through the film. According to this model, if intra-particle diffusion is the step of controlling the adsorption rate, then the diagram $B_{t}: t$ (Fig. 8) gives a straight line passing through the coordinate onset which is present in the specific case. If not, then the limiting step would be the film diffusion (external mass transfer) or a chemical reaction.

Slightly weaker, but again a quite high value of statistical parameters of suitability $\left(R^{2}=0.981-0.938\right.$; SSE $=0.135-7.487 ; R M S E=0.150-1.117$ ) obtained from the Weber\&Morris model for the diffusion and sorption of dye on PET fibers show that the intra-particle diffusion model is a limiting step, which is in agreement with the Boyd model. A higher concentration of the solution (from 20 to $120 \mathrm{mg} \mathrm{dm}^{-3}$ ) increases a constant rate of the diffusion within the particles (of 0.18 to $0.73 \mathrm{mg} \mathrm{g} \mathrm{min}^{-0.5}$ ) and the effect of the diffusion within the particles.

A slightly lower value of the statistical parameter obtained from the Film diffusion model for the diffusion and the sorption of the dye to adsorbent indicate that the diffusion through the film model is not the only limiting step. Initially, the adsorption to the outer surface or rapid adsorption through the layer on the fiber surface occurs, followed by the diffusion within the fiber (a limiting step) with equilibrium at the end.

The diffusion within the particles during dyeing of PET fibers cannot exist if the adsorbent is non-porous, and accordingly, it can be stated that a pretreatment with alkali under ultrasound conditions made the fibers more porous and more permeable to a disperse yellow dye.

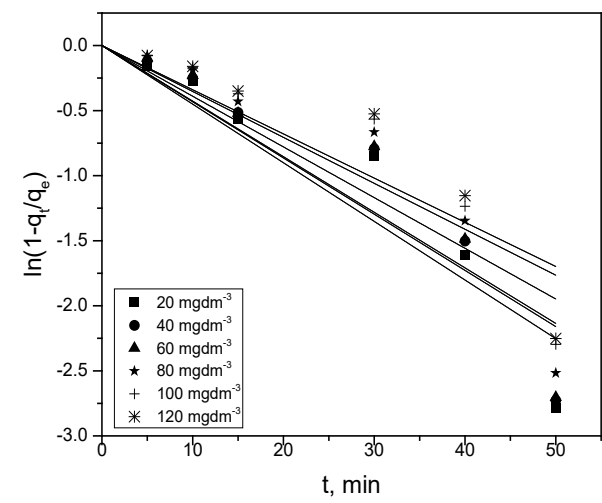

Figure 9. Adsorption kinetic of disperse yellow dye according to the Film diffusion mechanistic model
Table 3. Parameters of kinetic diffusion models with statistical error parameters

\begin{tabular}{|c|c|c|c|}
\hline \multirow[t]{2}{*}{ Kinetic models } & \multirow[t]{2}{*}{ Parameters } & \multicolumn{2}{|c|}{$\begin{array}{l}\text { Initial dye concentration, } \\
\qquad \mathrm{mg} \mathrm{dm}^{-3}\end{array}$} \\
\hline & & 20 & 120 \\
\hline \multirow{4}{*}{ Weber\&Morris } & $k w M(\mathrm{mg} \mathrm{g} \mathrm{min}-0.5)$ & 0.184 & 0.735 \\
\hline & SSE & 0.135 & 7.487 \\
\hline & $R^{2}$ & 0.981 & 0.938 \\
\hline & RMSE & 0.150 & 1.117 \\
\hline \multirow{4}{*}{ Boyd } & $B\left(\mathrm{~s}^{-1}\right)$ & 0.028 & 0.022 \\
\hline & SSE & 0.061 & 0.114 \\
\hline & $R^{2}$ & 0.985 & 0.958 \\
\hline & RMSE & 0.110 & 0.151 \\
\hline \multirow{4}{*}{ Film difussion } & $K_{F D}\left(\mathrm{mg} \mathrm{dm}^{-3}\right)$ & 0.045 & 0.034 \\
\hline & SSE & 0.621 & 0.659 \\
\hline & $R^{2}$ & 0.946 & 0.903 \\
\hline & RMSE & 0.352 & 0.363 \\
\hline
\end{tabular}

According to the results of similar researches by other researchers during the dyeing of the polyester fabric with disperse dye in supercritical $\mathrm{CO}_{2}$ on the Weber\&Morris equation diagram, the initial curved parts of the fitting curve are attributed to the diffusion through the boundary layer, the linear part is attributed to the diffusion within particles, the plateau to equilibrium follows at the end. Since the equation curve does not pass through the coordinate origin, this means that the border layer has a degree of control, that is, the diffusion within the particles is not the only rate control step. Of course, other processes can control the adsorption rate, and they can all do this simultaneously. The correlation coefficients for the intra-particle diffusion model are between 0.872 and 0.964 . This indicates that the adsorption on the polyester fabric can follow a particle diffusion model for up to $60 \mathrm{~min}$ at $95^{\circ} \mathrm{C}$. The border layer resistance is affected by the adsorption rate and the increase in contact time, which decreases the resistance and increases the mobility of the dye during adsorption [7].

\section{Conclusion}

Regarding the obtained results, it can be concluded that the previously modified PET fibers by using calcium hydroxide and ultrasound can be significantly dyed by the usual disperse yellow dye without carrier, at a boiling point.

Processing that precedes the dyeing changes the surface morphology which increases the permeability and improves the adsorption or dyeing properties. With the increase of the initial dye concentration, a degree of the exhaustion decreases and the adsorption capacity increases continuously over a period of time. 
During dyeing, a gradual decreasing change in the color concentration is noticeable, initially more intense, and later somewhat slower, as well as a gradual increase in the adsorption capacity.

Modified Freundlich equation is the most effective of the kinetic reaction models, whereas Boyd equation is the most suitable of all kinetic diffusion models in linear simulation of the kinetics of dyeing PET fibers by a disperse yellow dye. The adsorption mechanism can be described by the dominant diffusion within the particles.

The results of this research suggest a different approach in the process of dyeing polyethylene terephthalate with a disperse dye, all in favor of greater exhaustion, savings and environmental protection.

\section{Acknowledgements}

The funds for the realization of this scientific work were provided by the Ministry of Education, Science and Technological Development of the Republic of Serbia.

\section{References}

[1] M. A. Iskender, B. Becerir, A. Koruyucu, Carrier Dyeing of Different Energy Level Disperse Dyes on Polyester Fabric, Textile Research Journal, 75(6) (2005) 462 - 465.

[2] S. M. Burkinshaw, Chemical Principles of Synthetic Fibre Dyeing, Blackie Chapman \& Hall, London,1995, p. 155.

[3] M. Aldib, R. Christie, Textile applications of photochromic dyes. Part 5: application of commercial photochromic dyes to polyester fabric by a solvent-based dyeing method, Coloration Technology, 129(2) (2013) 131 - 143.
[4] N. A. Ibrahim, M. A. Youssef, M. H. Helal, M. F. Shaaban, Exhaust Dyeing of Polyester-Based Textiles Using HighTemperature-Alkaline Conditions, Journal of Applied Polymer Science, 89(13) (2003) 3563 - 3573.

[5] L. Wang, H. F. Zhaoa, J. X. Lin, Studies on the ultrasonicassisted dyeing of poly(trimethylene terephthalate) fabric, Coloration Technology, 126(4) (2010) 243 - 248.

[6] G. Mohamad, R. Abousaeed, T. Habib, Adsorption Behavior of Disperse Orange 30 on Polyester Fabric, World Applied Sciences Journal, 14(9) (2011) 1291 - 1295.

[7] A. S. Ozcan, A. Ozcan, Adsorption behavior of a disperse dye on polyester in supercritical carbon dioxide, Journal of Supercritical Fluids, 35(2) (2005) 133 - 139.

[8] C. F. Natali, P. B. Rodrigo, L. C. Eder, C. Tatiana, A. V. Camila, R. Betina, C. L. Marta, F. H. M. Thais, S. P. Isis, Removal of remazol black $B$ textile dye from aqueous solution by adsorption, Desalination, 269(3) (2011) 92 103.

[9] K. N. Ashish, P. Anjali, Development and validation of an adsorption kinetic model at solid liquid interface using normalized Gudermannian function, Journal of Molecular Liquids, 276 (2019) 67 - 77.

[10] C. O. Aniagor, M. C. Menkiti, Kinetics and mechanistic description of adsorptive uptake of crystal violet dye by lignified elephant grass complexed isolate, Journal of Environmental Chemical Engineering, 6 (2018) 2105 2118.

[11] X. Weilin, Y. Chaoli, Hydrolysis and dyeing of polyester fabric using microwave irradiation, Coloration Technology, 118(5) (2002) 211 - 214.

[12] X. Weilin, L. Xin, Surface modification of polyester fabric by corona discharge irradiation, European Polymer Journal, 39 (2003) 199 - 202.

Izvod

\section{KINETIKA SORPCIJE DISPERZNE BOJE NA MODIFIKOVANI POLIETILEN TEREFTALAT}

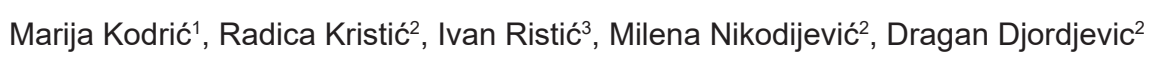

${ }^{1}$ Univerzitet u Nišu, Inovacioni centar Univerziteta u Nišu, Serbia

2Univerzitet u Nišu, Tehnološki fakultet, Leskovac, Serbia

3 Univerzitet u Novom Sadu, Tehnološki fakultet, Novi Sad, Serbia

Članak obrađuje problematiku vezanu za kinetiku procesa bojenja modifikovanog polietilen tereftalata disperznom bojom. Modifikacija vlakana obuhvata obradu vodenim rastvorom gašenog kreča uz istovremeno delovanje ultrazvučnih talasa. Bojenje vlakana je izvršeno diskontinualno-šaržni proces, uz promenu početne koncentracije boje (20 - $\left.120 \mathrm{mg} \mathrm{dm}^{-3}\right)$ i vremena bojenja (5 - $\left.60 \mathrm{~min}\right)$. Korišćeno je nekoliko kinetičko reakcionih (Pseudo prvi, Avrami i Modified Freundlich) i difuzionih (Weber\&Morris, Boyd i Film diffusion) modela za testiranje eksperimentalnih podataka iz procesa bojenja. Konstatovano je da bojenje modifikovanih vlakana daje bolje rezultate od bojenja nemodifikovanog poliestra, pri istim uslovima. Sa porastom početne koncentracije boje smanjuje se stepen iscrpljenja $(76,2-57,4 \%$, za ravnotežno vreme bojenja) a raste apsorpcija disperzne boje po jedinici mase vlakana $\left(1,5-6,9 \mathrm{mg} \mathrm{g}^{-1}\right.$, za ravnotežno vreme bojenja). Tokom bojenja opada početna koncentracije boje, dok raste kapacitet adsorpcije. Linearna simulacija kinetičkih parametara bojenja pokazala je da reakcijski model Modified Freundlich dominira, dok je od kinetičkih modela difuzije jednačina Boyd-a bila najpovoljnija.
(ORIGINALNI NAUČNI RAD) UDK 677.027:678.742.2

Ključne reči: polietilen tereftalat, modifikacija, gašeni kreč, ultrazvuk, disperzna boja, kinetički modeli. 